\title{
STUDY ON THE DIAGENETIC CALCAREOUS ACCUMULATIONS IN A SOIL PROFILE FROM FLOREŞTI (CLUJ COUNTY, ROMANIA)
}

\author{
HOREA BEDELEAN ${ }^{1}$
}

\begin{abstract}
The studied calcretes developed in two different levels (horizons) in the soil profile from Floreşti (Cluj County). The deposits outcropping in the area are represented by Bartonian-Priabonian sedimentary rocks (Ciuleni Member, Viştea Limestone) and the Quaternary horizon (terrace of Someşul Mic River, consisting of pebbles of different origin), which represent the parent rock of the soil. A detailed petrographical and mineralogical description of the calcretes is given below, based on macroscopic, microscopic and X-ray diffraction analysis. It led to the conclusion that the calcretes from the studied profile have a pedogenic origin. The calcretes consist of distinctive subhorizons within the host horizon of the soil. According to their microstructure, the studied calcretes belong to the alpha-type and may be considered as "nodular calcretes" or "glaebular calcretes". The source of carbonate was variable: from the parent material of the soil including fragments of carbonate rocks, bioclasts, vegetal rests, eolian dust.
\end{abstract}

Key words: Calcretes, Floreşti (Cluj County), soil

\section{INTRODUCTION}

Calcretes have been defined as $\mathrm{CaCO}_{3}$-rich accumulations formed in terrestrial environments, close to the Earth's surface; they show a high morphological variety, from earthy - to nodular types, up to "indurated" levels. Their genesis is related to the dissolution-precipitation processes within soil profiles, sediments or sedimentary rocks. The deposition of $\mathrm{CaCO}_{3}$ from solutions may take place either in soils, in aquiferous levels beneath the soil, in the upper part of the capillary zone, or even below the piesometric level. The term "terrestrial carbonate accumulation" that is used for calcretes is meant to separate this special type of deposit from those resulting from other accumulation processes that lead to the formation of carbonate tuffs, travertine, or of other terrestrial carbonate deposits.

Most of the calcrete accumulations occur within the soil cover (being defined as "pedogenic calcretes"), and mainly develop in areas with a seasonal precipitation deficit that allows the carbonate precipitation.

Calcretes showed a similar temporal distribution in the past, being identified even in Precambrian deposits; they are used as an index for paleoclimate and piesometric level change evaluations.

Recent studies were carried out on the detailed description, origin, characteristic features and environmental control of the development of pedogenic calcretes (Alonso-Zarza, 2003; Khadikikar, 2005; Jimenez-Espinoza \& Jimenez-Milan, 2003; Borchardt \& Lienkaemper, 1999; Royer, 1999).

\footnotetext{
${ }^{1}$ Department of Geology, "Babeş-Bolyai” University, Cluj, Kogălniceanu 1, 400084 Cluj, Romania (bedelean@bioge.ubbcluj.ro)
} 


\section{HOREA BEDELEAN}

\section{TERMINOLOGY - TYPES OF CALCRETES}

Calcretes were defined in by Netterberg (in Hay \& Reeder, 1978) as: "any terrestrial material which has been cemented and/or replaced by dominantly $\mathrm{CaCO}_{3}$...cave deposits excluded... the mechanism of calcification is not restricted and calcretes may be of pedogenic or non-pedogenic origin, or both". The calcretes described herein are developed in soil deposits (profile), so they are pedogenic in origin. Pedogenic calcretes can constitute discrete horizons within the soil (Wright \& Tucker, 1991).

There are several types of classifications. Calcretes can be classified based on morphology (Netterberg 1967 \& 1980 cited by Wright \& Tucker, 1991), or by taking into account the stages of their evolution. Machette (1985) proposed a new system of classification, assuming six evolutionary stages. Calcretes can also be classified according to their mineralogical composition (dolomite content) as well as based on their hydrological setting.

Another criterion is represented by microstructure (Fig. 1), two extreme types being identified (Wright, 1990): alpha and beta calcretes. The alpha calcretes, consist of dense and continuous microfabric of micritic - microsparitic groundmasses (Wright \& Tucker, 1991), nodules, circumgranular and complex cracks with crystallaria (single crystals, or arrangements of crystals of calcite, developed in voids or cracks, due to a local accumulation of gases and solutions, after the desiccation processes or expansive growth) large euhedral crystals, usually rhombohedral in shape, and sedimentary grains.

\section{ALPHA}

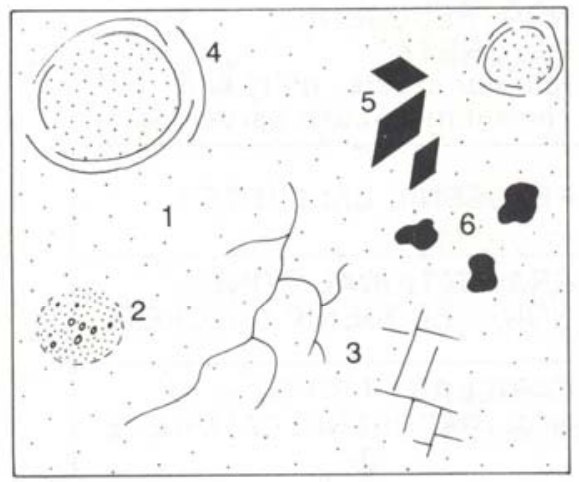

BETA

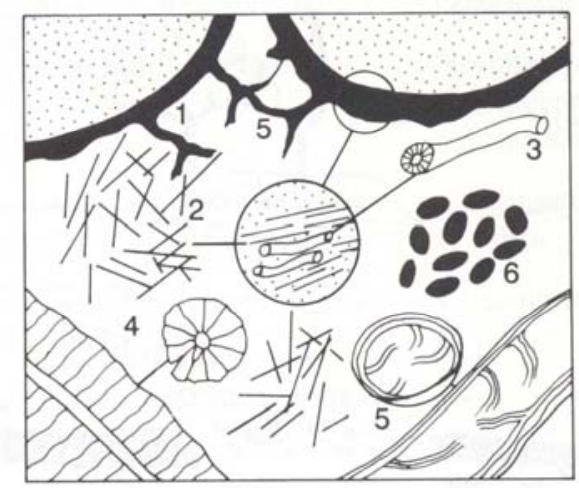

Fig. 1. Micromorphological classification of calcretes (after Wright, 1990, in Wright \& Tucker, 1991). Alpha calcretes: 1. dense microfabric; 2 nodules; 3 complex cracks and crystallaria; 4 circumgranular cracks; 5 rhombic calcite crystals; 6 floating sediment grains. Beta calcretes: 1 microbial coatings; 2 needle fibre calcite; 3 calcified tubules; 4 Microcodium; 5 alveolar septal fabric; 6 calcified pelletes.

The beta calcretes occur in textures rich in carbonates, and show biogenicdominant microstructures such as rhizocretions, needle-fibre calcite, and microbial tubes, alveolar fabric and Microcodium. Within such structures, carbonate partly precipitated in relationship to fungi or other types of microorganisms (Wright \& Tucker, 1991). 


\section{MATERIALS AND METHODS}

The material used in this study consisted of samples of calcretes developed in two different levels (horizons) in the soil profile from Floreşti (Cluj County). The studied area is located in the northwestern part of the Transylvania Depression between Cluj-Napoca and Huedin.

A moderate continental climate characterizes the region. The mean annual temperatures vary between $+2^{\circ}$ and $+6^{\circ} \mathrm{C}$ in Gilău area and between +7 and $+9^{\circ} \mathrm{C}$ in the whole Transylvanian Depression. The average annual relative humidity is $75-80 \%$.

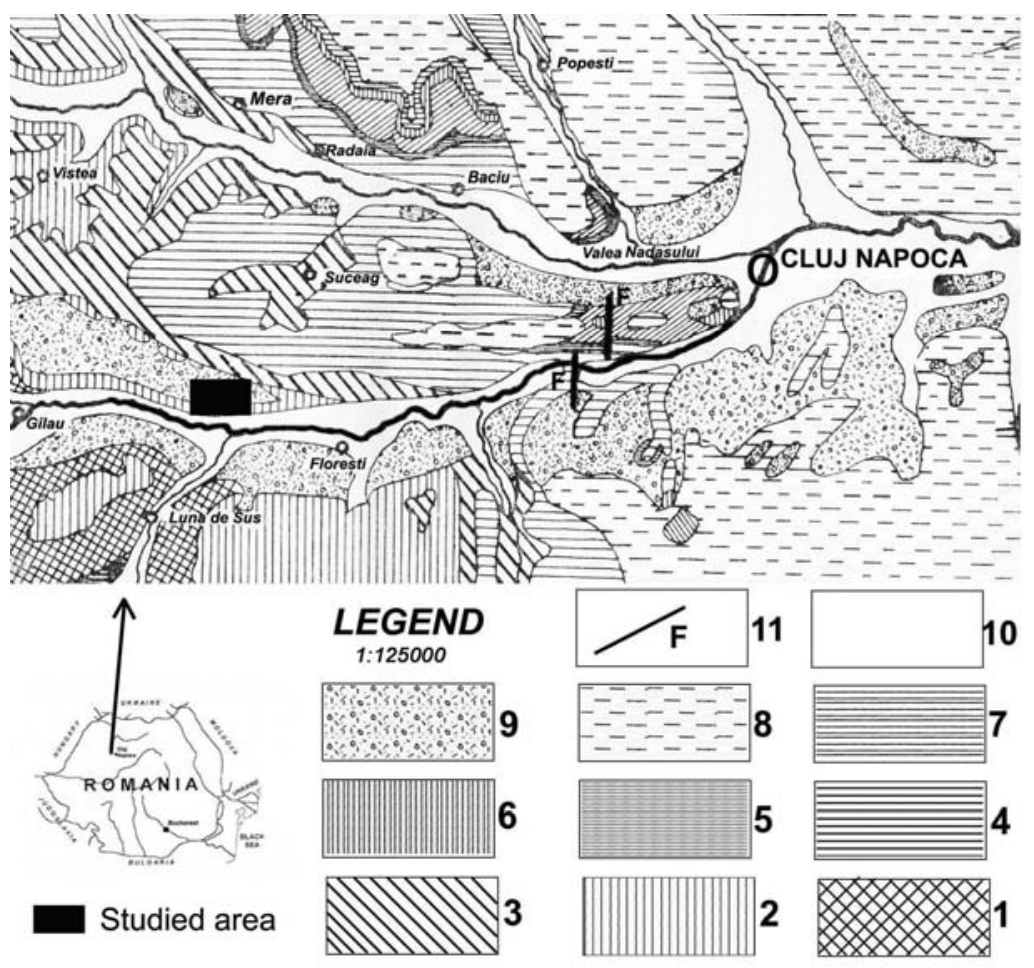

Fig. 2. Geological sketch of the Floreşti area (Cluj county), with the location of the studied area (modified after Meszaros\&Nicorici, 1976). Legend: 1-Jibou Formation (Late MastrictianLate Lutetian); 2-Călata Group (Bartonian-Lower Priabonian; 3-Valea Nadăşului Formation (Priabonian); 4-Jebuc Formation+Cluj Limestone+ Brebi Formation (Priabonian); 5-Hoia Limestone+Mera Formation (Lower Rupelian); 6-Moigrad Formation+Dancu Formation+Gruia Sandstone+Var Sandstone (Rupelian); 7-Cuzăplac Formation+Cubleşu Formation+Sancraiu Formation (Egerian); 8-Badenian; 9-Terraces of Someşul Mic River; 10-Alluvium; 11-Fault.

The geological deposits outcropping in the area are represented by BartonianPriabonian sedimentary rocks: Călata Group also known as the „lower marine series” groups together the following marine lithostratigraphic units: Foidaş Formation, Căpuş Formation, Mortănuşa Formation, (Inucu Member, Văleni Limestone, Ciuleni Member), Viştea Limestone (Fig. 2). 


\section{HOREA BEDELEAN}

Ciuleni Member represents the uppermost subunit of the Mortănuşa Formation, corresponding to the "sandy marls with ostreids" (Meszaros, 1960). It consists of grey and grey-greenish fine deposits with intercalations of sands and bioclastic calcarenites with ostreids, pectinids, ostracods and formainifera (Filipescu, 2001).

Viştea Limestone, the uppermost formation of the Călata Group is represented by a bioclastic bar, about $8 \mathrm{~m}$ thick, consisting of calcarenites, biomicrites and dolomicrites with siliciclastic intercalations, deposited in a very shallow marine environment. The fossil record includes coralline algae, calcareous micro- and macro-foraminifers, molluscs, echinoids etc. Both stratigraphical units outcrop in the neighbourhood of the studied soil profile.

The specific appearance of Someşului Mic Valley upstream Cluj Napoca is due to the geological features overlapped by the typical Quaternary morphoclimatic cycles.

In the upper course, the valley shows a cuesta-type ridge accompanied by an assembly of alluvial terraces; among them, only the three lower terraces are well-preserved, the other having been destroyed by the slope weathering processes during the Upper Pleistocene.

Terrace no. III (20-22 metres relative altitude) consists of a thin and interrupted alluvial complex (subangular and subrounded pebbles) overlaid by a supra-alluvial formation, up to 20 metres thick, consisting of a complex of palaeosoils and loess-derivatives of an Upper Pleistocene age (Pendea et al. oral communication, 2004). Secondary carbonates occur at different levels. Terrace no. III is well developed on the left slope of the valley.

Terrace no. II (10-15 metres relative altitude) consists of a basal coarse level followed by finer deposits (silt) that represent the ground for the present soil cover. It mainly occurs on the right slope of the valley.

The lower terrace (of the river meadow) is developed alternatively on both sides of the river, and the coarse level in the base is relatively thick.

Currently, the river Someş crosses the above-mentioned coarse deposits leading to the extension of the meadow. During Holocene these deposits were characterized by numerous bends.

In the studied area, on the top of the Ciuleni Member a Quaternary horizon crops out (which constitute the terrace no. III of Someşul Mic River), built-up of pebbles of various origins: mainly metamorphic (quartzites, sericite and chlorite schists, quartzite and gneisses), but also sedimentary (limestones, soft clayey pebbles), and magmatic (acidic-granitic rocks, and pegmatites) in nature.

Follows a paleosoil level of $\sim 1.5 \mathrm{~m}$ thick, that hosts the first calcrete subhorizon. On its top, the current soil cover develops on about $1.6 \mathrm{~m}$ and it also contains calcretes (Figs. 3, 4). A detailed petrographical and mineralogical description of the calcretes is given below.

The mineralogy was determined by X-ray diffraction (XRD) on carbonate and noncarbonate fractions. The noncarbonate fraction of the samples (calcretes) was obtained by crushing and sieving $(0.2 \mathrm{~mm}$ mesh), followed by dissolution of the carbonate in $10 \% \mathrm{HCl}$.

The thin sections of the analyzed samples were studied by using an optical microscope, in parallel-polarized light, with parallel and crossed nicols. 


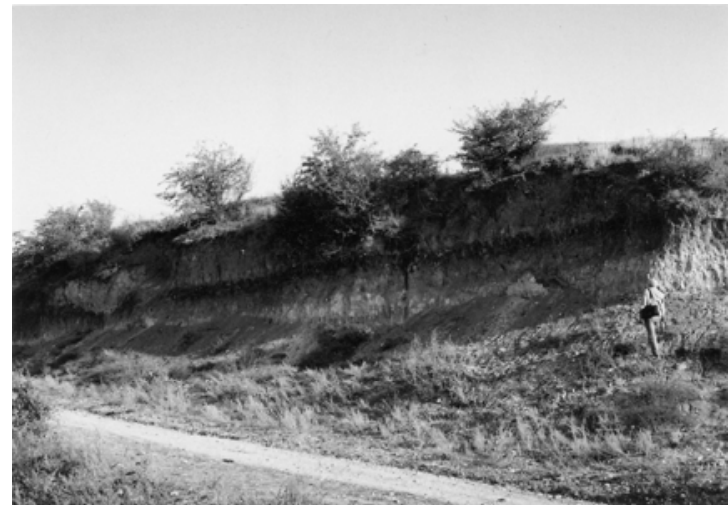

Fig. 3. Soil profile in the Floreşti area (Cluj County).

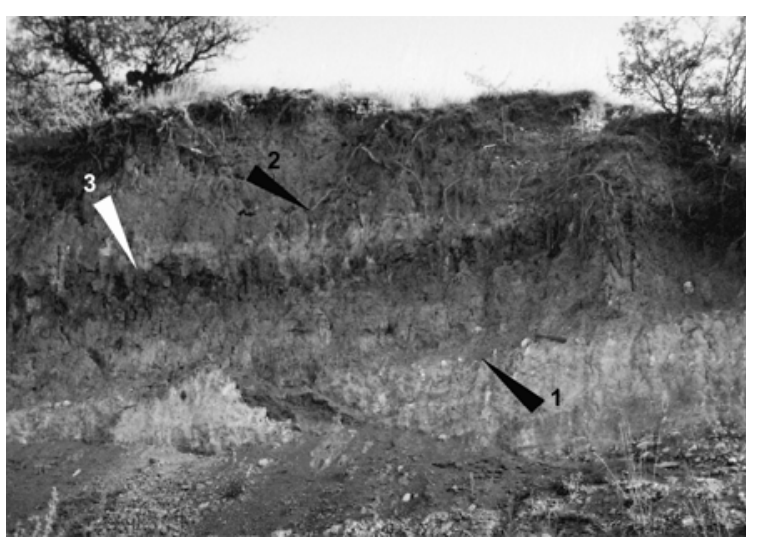

Fig. 4. Soil profile from Floreşti showing two pedogenic calcretes horizons (1, 2). 3 - The boundary between soil and paleosoil evidenced by the presence of an erosional surface

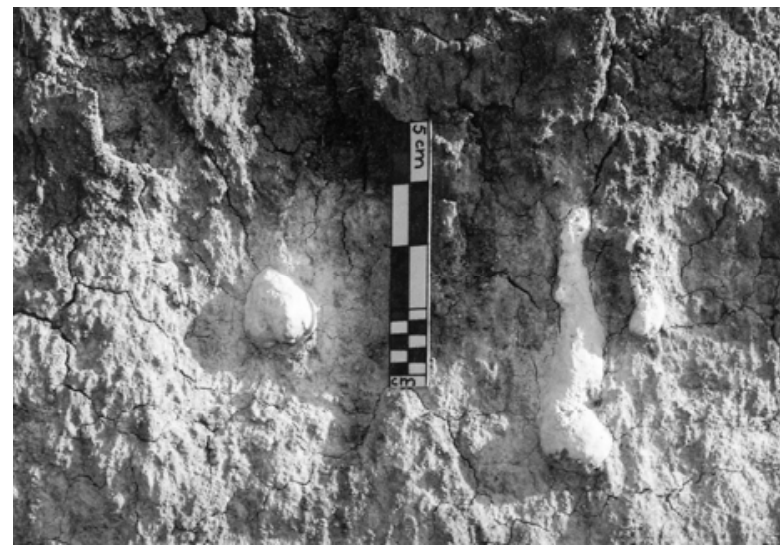

Fig. 5. Elongated, "tear"-like calcretes in the buried soil (level no.1, in Fig. 4) from Floreşti area (Cluj County). 


\section{HOREA BEDELEAN}

\section{RESULTS}

\section{Macroscopic features}

On top of the terrace no. III deposits containing pebbles, a $1.5 \mathrm{~m}$ thick Quaternary paleosoil level rich in calcium carbonate outcrops (Fig. 5). Root-channels some showing organic alteration patterns, the development of a reddish clay level, $40 \mathrm{~cm}$ thick, and the presence of numerous calcrete concretions represent the peculiarities of this level. The upper part of this level is brownish-black, indicating a relative higher amount of organic matter; locally it contains carbonate material, but no calcrete nodules were identified.

The calcretes occuring in this level are elongated and show "tear"-like shapes (narrower towards the upper part) (PI. I, Fig. 1). Their length is between 5-6 $\mathrm{cm}$ in the lower level and $20-25 \mathrm{~cm}$ towards the top of the horizon, where a proper calcrete subhorizon can be defined. The colour is white-yellowish. A rounded surface is typical, and the sizes increase with the proximity of the surface. The current "tear"-like shape is influenced by the action of the humic acids in the soil.

On the top of an erosional surface (marked by channels filled with rounded clasts) the actual soil level develops. Also the current soil level hosts local carbonate accumulations, even a calcrete subhorizon is noticeable, but the formation is less developed and brecciated.

Here the calcretes show platy, rounded and slightly elongated morphologies (PI. I, Fig. 1); their length is up to $10 \mathrm{~cm}$ and they are reddish in colour.

The calcretes have been sectioned transversally to the elongation. The break shows fissures and dissication traces that are typical for the crystallization of the carbonate from gels; an external rim, darker in colour and about 2-3 $\mathrm{mm}$ thick is noticeable (PI. I, Figs. 2, 3). Rests of clay, possibly previous growth nuclei are also present.

\section{Microscopic features}

The microscopic specimens were obtained as transversal section within the calcretes; they evidenced, as indicated also by other investigation methods, a dominant carbonate component and a non-carbonate subordinated one.

The matrix consists almost entirely of micritic carbonates (PI. I, Figs. 4, 5). Calcite is the main authigenic mineral. The calcite is micritic, whereas microspar is present only along fissures and voids as a result of diagenesis. The micritic matrix also contains large euhedral calcite crystals, probably formed subsequently in the pores. Frequent bioclasts (rests of foraminifers, bryozoa, echinoderms, etc.) embedded in the matrix from the parent rock are also visible (PI. II, Fig. 5).

The non-calcite fraction of the calcretes is formed of primary mineral grains (quartz, mica), rock fragments (quartzite) (PI. II, Fig. 3).

Quartz is angular, shows normal extinction and subordinately an undulatory one (5-6\%). Within the calcretes from the lower level, corona-type sparitic calcite formed around the quartz crystals (PI. II, Figs. 1 to 4 ).

Mineral grains, such as quartz are etched and replaced to varying extents by calcite. Most of the replacement in the calcrete represents the precipitation of calcite around previously corroded grains.

Muscovite is present as microlamellae, in subordinate amounts (1-2\%); it originates from the parent rock of the soil. Iron oxides and organic matter (black in colour), probably represented by humus occur along the fissures. 
Structurally, the thin sections show a series of "cracks" filled with calcite, called "crystallaria” (including circumgranular types) (PI. I, Fig. 5). Their formation is related to the local accumulation of gases and solutions, as a result of dissication processes or of expansive growth (Wright \& Tucker, 1991). They may show various shapes, sizes and orientations.

Sometimes, "micronodules" associations develop along the cracks and in voids, suggesting a diagenetic origin (PI. II, Figs. 6, 7).

\section{$X R D$ analysis}

XRD patterns were taken on microsamples from both the central and the internal part of the calcretes. Both types indicated an almost entirely carbonate composition, i.e. calcite. In the samples from level I, the calcium carbonate (calcite) content is about $89.4 \%$ in the 7 analysed samples.

In the calcretes from level II, the calcium carbonate content is in average $92.17 \%$ in the 5 analyzed samples (Fig. 6).

The non-carbonate fraction represents about $10.6 \%$ from the calcrete mass in the lower level, and about $7.83 \%$ in the upper level. Mineralogical, the XRD analyses showed the presence of quartz and muscovite and to a lesser extent that of illite (Fig. 7).

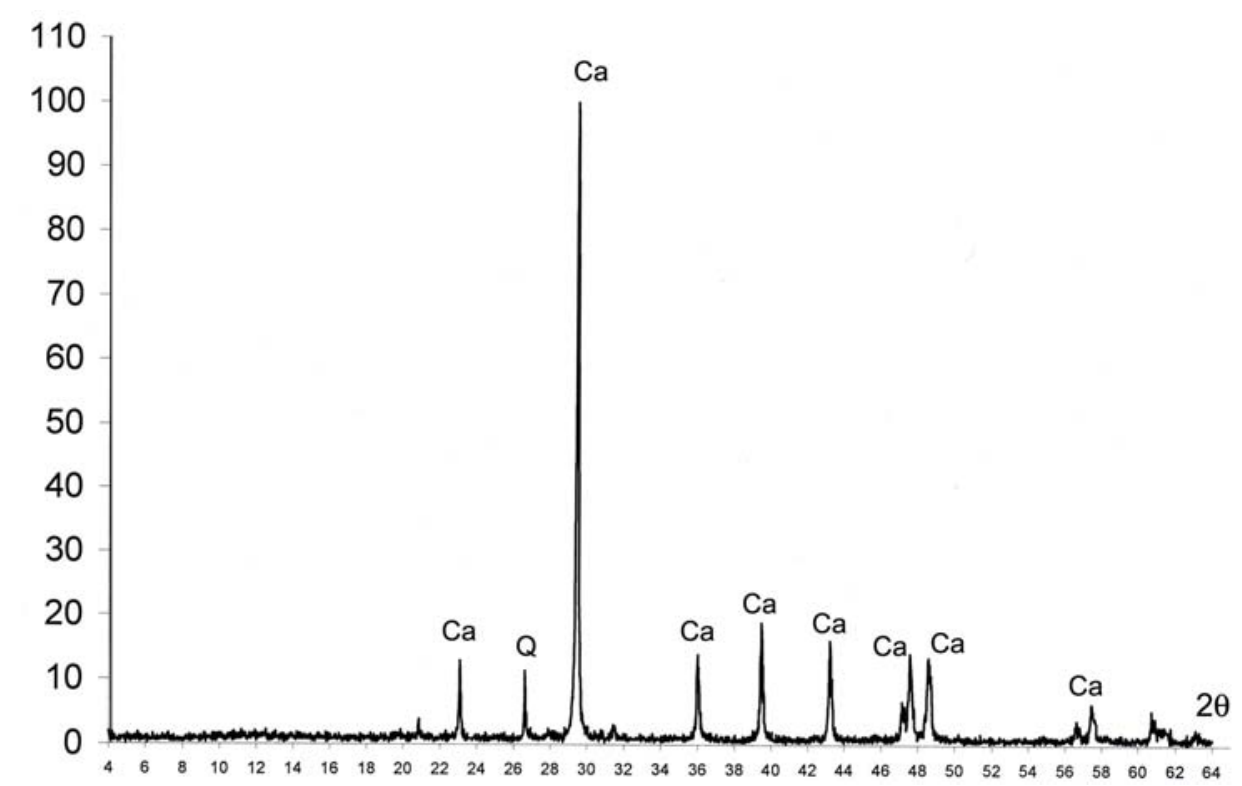

Fig. 6. XRD patterns of the calcretes, before the dissolution of the carbonate in $\mathrm{HCl}$. (Ca=calcite; $Q=q u a r t z)$

The non-calcite fraction of the calcretes is a mixture of inherited and authigenic materials. Primary mineral grains, rock fragments, generally form the largest amount of the acid-insoluble residue. Generally, less common are clay minerals (authigenic illite). 


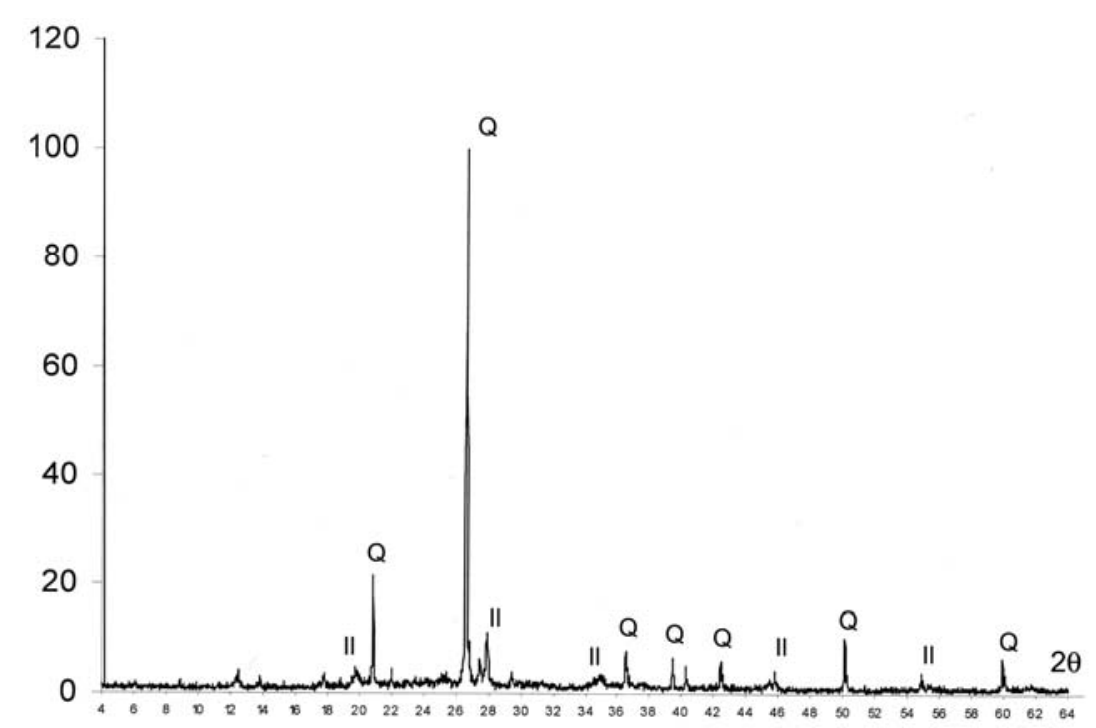

Fig. 7. $X R D$ patterns of the non-calcite fraction of the calcretes from Floreşti (Cluj County), after the dissolution of the carbonate in $\mathrm{HCl}(\mathrm{Q}=$ quartz; $/ /=$ illite).

\section{CONCLUSIONS}

The calcretes from the studied profile from Floreşti (Cluj County) have a pedogenic origin. This is proven by a series of specific features such as the brecciated aspect, the presence of relatively high amounts of organic matter (humus), the unambiguous indications of displacive evolution of granular quartz, and its carbonate coating. Displacive growth appears to be the dominant process in the formation of alpha-fabric. Such features as grain fracturing and "floating grains" are directly attribuable (belong) to this process.

The calcretes constitute distinctive subhorizons within the host horizon of the soil. A very typical feature of pedogenic calcretes is their fast growth: only some thousands of years are needed for their maturation. This is a consequence of a "very high supply rate" of calcium carbonate from the carbonate dust.

According to their microstructure, the studied calcretes belong to the alphatype (PI. I, Figs. 4, 5). They consist of dense and continuous masses of micrite microsparite that forms the matrix, nodules, circumgranular and complex cracks with crystallaria - large euhedral crystals usually rhomboidal, and clastic grains. The typical biogenic features of beta-type calcretes are missing. The rests of bioclasts resulted from the parent material of the soil. The depth of calcrete formation was characterized by a reduced biological activity.

According with the Netterberg morphological classification $(1967,1980)$ (in Wright \& Tucker, 1991) the calcretes from the soil at Floreşti may be considered as "nodular calcretes" or "glaebular calcretes".

The source of carbonate was variable. It mainly originated from the parent material of the soil including fragments of carbonate rocks, bioclasts, and vegetal rests. In general, in the levels with abundant $\mathrm{CaCO}_{3}$ contents, calcretes were formed by a simple redistribution of the carbonate. 
Other sources of carbonate are the surface waters, precipitations and especially the eolian dust; in the neighbourhood of the studied profiles numerous outcrops of limestones are present. The $\mathrm{CaCO}_{3}$-rich dust was accumulated at the surface of the soil and then dissolved by the meteoric water, transported to depth (carbonate illuviation processes) and precipitated at the level reached by the seasonal humidity, in a moderately cold and dominant dried climate, typical for the period. (Pendea et al., pers. comm.). This 'per descensum' mechanism is the best to explain the formation of calcretes high above the piesometric level and in noncarbonate beds.

\section{REF E R NCES}

Alonso-Zarza, A.M. 2003, Palaeoenvironmental significance of palustrine carbonates and calcretes in the geological record. Earth-Science Reviews, 60: 261- 298.

Borchardt, G., Lienkaemper, J. J. 1999, Pedogenic calcite as evidence for an early Holocene dry period in the San Francisco Bay, California. Geol. Soc. of America Bulletin, 111 (6): 906-918.

Filipescu, S. 2001, Cenozoic Litostratigratigraphic Units. In Transylvania, Field Trip Guide, $4^{\text {th }}$ Regional Meeting of IFAA, Cluj University Press, pp. 75-92

Hay, R. L., Reeder, R. J. 1978, Calcretes of Olduvai Gorge and the Ndolanya Beds of northern Tanzania. Sedimentology, 25: 648-673.

Jimenez-Espinoza, R., Jimenez-Milan, J. 2003, Calcrete development in Mediterranean colluvial carbonate systems from SE Spain. Journal of Arid Environments, 53: 479-489.

Khadikikar, A. S. 2005, Elemental composition of calcites in late Quaternary pedogenic calcrete from Gujarat, western India. Journal of Asian Earth Sciences, 25: in press.

Machette, M. N. 1985, Calcic soils of the south-western United States. Geol. Soc. Am. Spec. Pap., No. 203: 1-21.

Meszaros N. 1960, Studiul litofacial şi paleogeografic al depozitelor marine Eocene medii de la vest şi sud-vest de Cluj. Studia Univ. "Babeş-Bolyai", Geol-Geogr., Serie II, fasc. 1 Cluj.

Meszaros, N., Nicorici, E. (coord.) 1976, Pe poteci cu banuței de piatră. Ed. Sport-Turism, Bucureşti, $190 \mathrm{pp}$.

Royer, D. L. 1999, Depth to pedogenic carbonate horizon as a paleoprecipitation indicator? Geology, 27 (12): 1123-1126.

Wright, V. P., Tucker, M. 1991, Calcretes, Blackwell Scientific Publications, 352 pp.

Wright, W. P., 1990, A micromorphological classification of fossil and recent calcic and petrocalcic structures. In: Soil Micromorphology: A Basic and Applied Science (Douglas, L. A., Ed.). Development in Soil Science, 19: 401-407, Elsevier, Amsterdam.

\section{Plate I}

\section{PLATES}

Fig. 1. Macroscopically features of the calcretes from the soil profile from Floreşti (Cluj County).

Fig. 2, 3. Sections in calcretes, with fissures and dissication traces.

Fig. 4, 5. Thin sections in calcretes. Micromorphological alpha type could be observed: adense microfabric; b-nodules; c-cracks and crystallaria; d-circumgranular cracks;

Plate II e-calcite crystals; f-sediment grains.

Fig. 1, 2. Quartz with corona-type sparitic calcite formed around the crystals.

Fig. 3 - Fragment of quartzite with corona-type sparitic calcite.

Fig. 4. The precipitation of calcite around a corroded grain of quartz.

Fig. 5. Bioclast in matrix of calcretes.

Fig. 6, 7. "Micronodules" of calcite, developed in voids of diagenetic origin. 
PLATE I
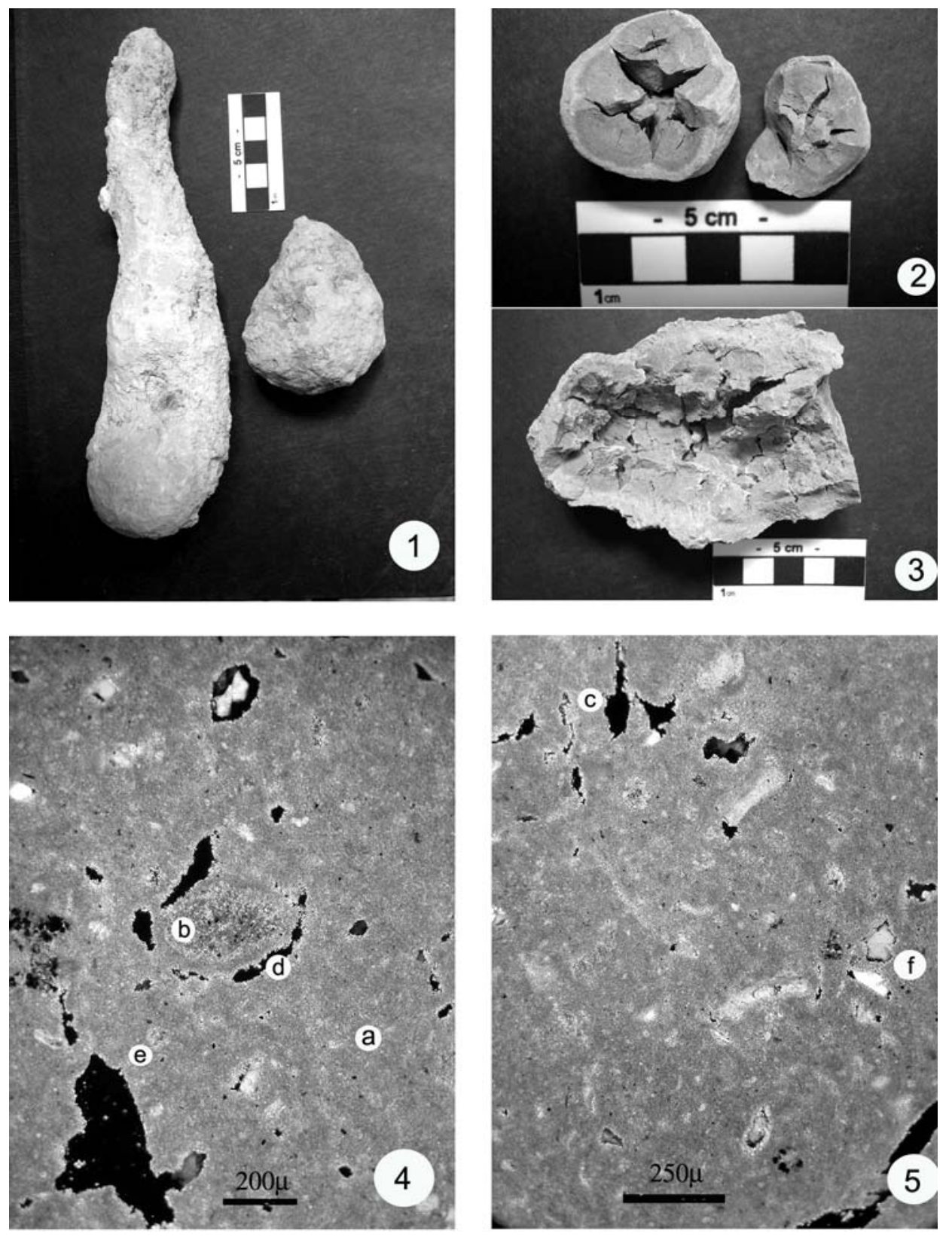
PLATE II
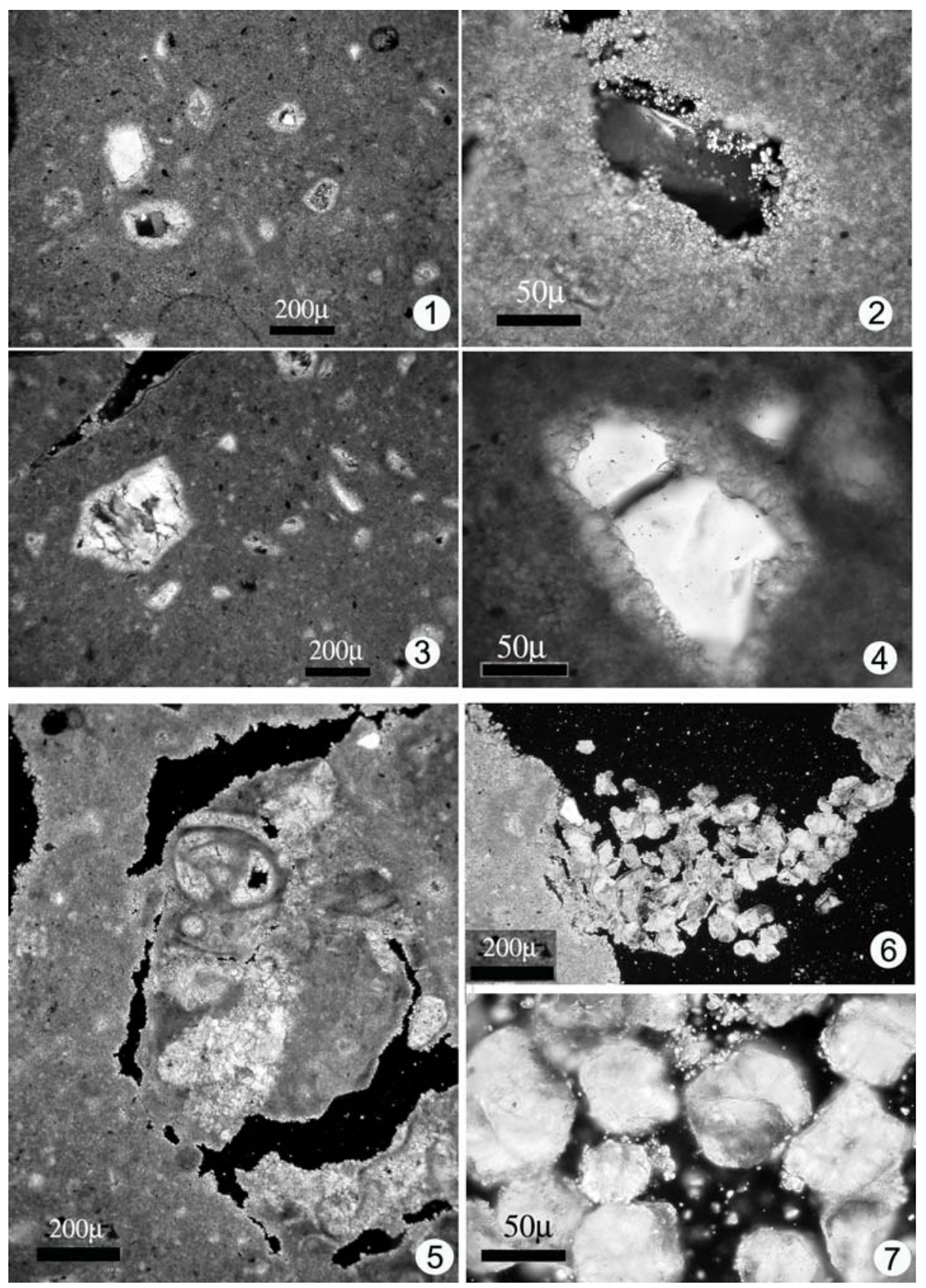